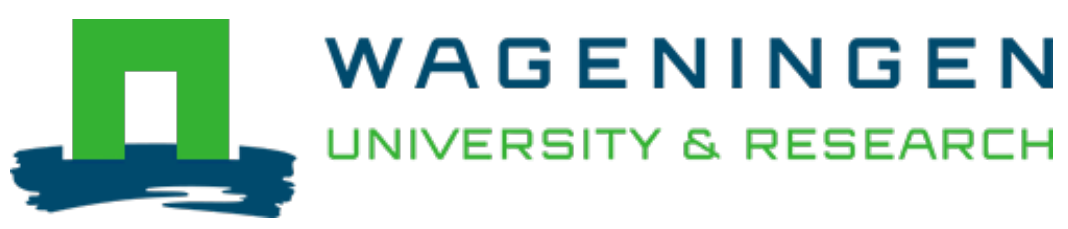

\author{
Nutrient composition of selected newly bred and established mung bean varieties \\ Food Science and Technology = Lebensmittel-Wissenschaft und Technologie \\ Dahiya, P.K.; Linnemann, A.R.; Nout, M.J.R.; Boekel, M.A.J.S.; Grewal, R.B. \\ https://doi.org/10.1016/j.lwt.2013.05.017
}

This publication is made publicly available in the institutional repository of Wageningen University and Research, under the terms of article $25 \mathrm{fa}$ of the Dutch Copyright Act, also known as the Amendment Taverne. This has been done with explicit consent by the author.

Article 25 fa states that the author of a short scientific work funded either wholly or partially by Dutch public funds is entitled to make that work publicly available for no consideration following a reasonable period of time after the work was first published, provided that clear reference is made to the source of the first publication of the work.

This publication is distributed under The Association of Universities in the Netherlands (VSNU) 'Article 25fa implementation' project. In this project research outputs of researchers employed by Dutch Universities that comply with the legal requirements of Article $25 \mathrm{fa}$ of the Dutch Copyright Act are distributed online and free of cost or other barriers in institutional repositories. Research outputs are distributed six months after their first online publication in the original published version and with proper attribution to the source of the original publication.

You are permitted to download and use the publication for personal purposes. All rights remain with the author(s) and / or copyright owner(s) of this work. Any use of the publication or parts of it other than authorised under article $25 \mathrm{fa}$ of the Dutch Copyright act is prohibited. Wageningen University \& Research and the author(s) of this publication shall not be held responsible or liable for any damages resulting from your (re)use of this publication.

For questions regarding the public availability of this publication please contact openscience.library@wur.nl 


\title{
Nutrient composition of selected newly bred and established mung bean varieties
}

\author{
P.K. Dahiya ${ }^{\mathrm{a}, \mathrm{b}, \mathrm{c}}$, A.R. Linnemann ${ }^{\mathrm{b}}$, M.J.R. Nout ${ }^{\mathrm{c}, *}$, M.A.J.S. van Boekel ${ }^{\mathrm{b}}$, R.B. Grewal ${ }^{\mathrm{a}}$ \\ ${ }^{a}$ Centre of Food Science and Technology, CCS Haryana Agricultural University, Hisar, Haryana, India \\ ${ }^{\mathrm{b}}$ Product Design and Quality Management Group, Wageningen University, Wageningen, The Netherlands \\ ${ }^{c}$ Laboratory of Food Microbiology, Wageningen University, Wageningen, The Netherlands
}

\section{A R T I C L E I N F O}

\section{Article history:}

Received 13 July 2011

Received in revised form

26 January 2012

Accepted 10 May 2013

\section{Keywords:}

Vigna radiata

Iron

Zinc

Calcium

In vitro accessibility

\begin{abstract}
A B S T R A C T
Seven newly bred and three established varieties of mung bean were analysed for proximate composition, minerals, anti-nutrients and in vitro mineral accessibility. They contained $18-23 \mathrm{~g}$ protein, $4.0-5.6 \mathrm{~g}$ crude fibre and $2.5-4.1 \mathrm{~g}$ ash per $100 \mathrm{~g}$ dry sample. Iron, zinc, calcium, sodium and potassium ranged from 3.4 to $4.6,1.2$ to $2.3,79$ to $115,8.1$ to 13.5 and 362 to $415 \mathrm{mg} / 100$ g dry weight, respectively. Phytic acid and polyphenols averaged 769 and $325 \mathrm{mg} / 100 \mathrm{~g}$ dry weight, respectively. Varieties differed significantly in terms of nutrient and anti-nutrient contents. Phytic acid and polyphenols were negatively correlated with in vitro mineral accessibility and nutrient digestibility. Protein and starch digestibility ranged from 53 to $67 \mathrm{~g} / 100 \mathrm{~g}$ dry weight and 20 to $29 \mathrm{mg}$ maltose released/g dry weight, respectively. Average molar ratios of phytic acid to iron and zinc were 16.8 and 52.7, respectively. Differences in in vitro iron and zinc accessibility could not be explained by phytic acid to calcium nor magnesium molar ratios. However, the phytic acid amount in mung beans suffices to bind all minerals into indigestible complexes. The newly bred varieties have better agronomic yields but no better nutritional potential than the established varieties tested.
\end{abstract}

(c) 2013 Elsevier Ltd. All rights reserved.

\section{Introduction}

Mung bean (Vigna radiata (L.) R. Wilczek) is an important legume in the diet of the majority of Indians, who consume it in different forms like dhals, sweets, snacks and savoury food products. Mung bean has a protein content comparable to that of chick pea (Cicer arietinum) but contains less anti-nutritional (Chitra, Vimala, Singh, \& Geervani, 1995) and flatulence factors than soya bean (Abdullah, Baldwin, \& Minor, 1984). Mung bean is rich in micronutrients and can be used to deliver minerals to malnourished populations if processed well to retain them in the diet. Mung bean varieties are grown in wide agro-climatic zones and have diverse agronomical, processing and nutritional characteristics (Bisht et al., 2005; Makeen, Abrahim, Jan, \& Singh, 2007; Tomooka, 1991). The suitability of a particular variety for processing and consumption depends primarily on its quality characteristics, particularly physical properties and chemical composition.

The presence of anti-nutrients such as phytic acid (PA) and polyphenols was shown to reduce the digestibility (Binita \&

\footnotetext{
* Corresponding author. Laboratory of Food Microbiology, P O Box 8129, $6700 \mathrm{EV}$ Wageningen, The Netherlands. Tel: +31 317 484339; fax: +31 317484978 .

E-mail addresses: rob.nout@wur.nl, rob@ronfostec.nl (M.J.R. Nout).
}

Khetarpaul, 1997) and bioavailability of nutrients present in mung bean (Dave, Yadav, \& Tarafdar, 2008; Mubarak, 2005). There are several approaches to increase nutrient bioavailability and digestibility at the primary production level. The first is by breeding varieties with better abilities to acquire nutrients from the soil, and the second is to optimize agronomic practices like fertilisation. Furthermore it is also possible to use breeding techniques for increasing the concentration of mineral enhancers like ascorbic acid and for decreasing the concentration of nutrient inhibitors like phytic acid, polyphenols, etc. (Frossard, Bucher, Machler, Mozafar, \& Hurrell, 2000).

Most of the mung bean breeding research in India has focused on high and stable yield, early and uniform maturity, resistance to pests, pathogens and drought (Singh \& Ahlawat, 2005). These selection criteria may have produced varieties with altered nutritional composition of the grains. Moreover, breeding for improved nutritional composition is limited by the fact that some plant components that are undesirable from nutritional point of view are physiologically important for the plant itself. For instance, phytic acid is required for seed germination, but it is detrimental to micronutrient uptake in humans (Coelho, Santos, Tsai, \& Vitorello, 2002).

To date, little effort has been made to evaluate the nutrient composition of new varieties of mung bean, which were bred for 
Table 1

Characteristics of the selected mung bean varieties.

\begin{tabular}{|c|c|c|c|c|c|}
\hline $\begin{array}{l}\text { Mung bean } \\
\text { varieties }\end{array}$ & & $\begin{array}{l}\text { Level of resistance to mung } \\
\text { bean yellow mosaic virus }\end{array}$ & Growing season & $\begin{array}{l}\text { Yield } \\
\text { (kg/hectare) }\end{array}$ & Crop duration (Days) \\
\hline $\begin{array}{r}\text { Established } \\
\text { varieties }\end{array}$ & $\begin{array}{l}\text { Asha } \\
\text { Muskan } \\
\text { Satya }\end{array}$ & $\begin{array}{l}\text { Tolerant } \\
\text { Resistant } \\
\text { Resistant }\end{array}$ & $\begin{array}{l}\text { Autumn } \\
\text { Autumn } \\
\text { Autumn }\end{array}$ & $\begin{array}{l}1000 \\
1000 \\
1300\end{array}$ & $\begin{array}{l}60 \\
80 \\
66\end{array}$ \\
\hline $\begin{array}{c}\text { Newly bred } \\
\text { varieties }\end{array}$ & $\begin{array}{l}\text { MH } 124 \\
\text { MH } 125^{\mathrm{a}} \\
\text { MH } 318 \\
\text { MH } 421 \\
\text { MH } 539 \\
\text { MH } 560 \\
\text { MH } 564\end{array}$ & $\begin{array}{l}\text { Resistant } \\
\text { Resistant } \\
\text { Resistant } \\
\text { Resistant } \\
\text { Resistant } \\
\text { Resistant } \\
\text { Resistant }\end{array}$ & $\begin{array}{l}\text { Autumn } \\
\text { Autumn } \\
\text { Autumn/Summer } \\
\text { Autumn/Summer } \\
\text { Autumn/Summer } \\
\text { Autumn/Summer } \\
\text { Autumn/Summer }\end{array}$ & $\begin{array}{l}1300 \\
1200 \\
1500 \\
1300 \\
1400 \\
1600 \\
1500\end{array}$ & $\begin{array}{l}65 \\
65 \\
58 \\
60 \\
60 \\
60 \\
60\end{array}$ \\
\hline
\end{tabular}

a Notified for farmers' use in 2009.

Source: Kumar, pers. comm. (2010) Senior Scientist at CCS Haryana Agricultural University, Hisar (India).

their disease resistance and high yield, and established varieties with respect to their contribution to human nutrition. Therefore, in the present study, seven newly bred varieties and three established varieties of mung bean were investigated for nutritional quality.

\section{Materials and methods}

\subsection{Sampling}

The mung bean varieties used for the study (Table 1) were grown using identical agronomic practices (e.g. fertilizer, irrigation) by the Department of Plant Breeding, CCS Haryana Agricultural University, Hisar, India. Raw, fully mature, disease-free mung bean grains were cleaned of extraneous matter, broken grains and weed grains, dust and other foreign materials, mixed well and ground to fine powder in an electric grinder (Cyclotec M/s Tecator, Hoganas, Sweden) and passed through a $0.5 \mathrm{~mm}$ sieve. Powders were stored in sealed air-tight plastic containers in a refrigerator at $5{ }^{\circ} \mathrm{C}$ until analysis.

Pepsin, pancreatin, pancreatic amylase and bile were obtained from Sigma-Aldrich Co. USA. All other reagents used for the analyses were of analytical grade and glassware was acid $(1 \mathrm{~g} / 100 \mathrm{~mL}$ $\mathrm{HCl}$ ) washed.

\subsection{Selection and description of mung bean varieties}

Ten mung bean varieties were selected, namely seven newly bred at CCS Haryana Agricultural University and three established in Haryana state in India.

\subsection{Analytical methods}

\subsubsection{Proximate composition}

The following AOAC methods (1990) were used to determine proximate composition: drying at $105{ }^{\circ} \mathrm{C}$ for $24 \mathrm{~h}$ for moisture (AOAC 925.10), incineration at $550{ }^{\circ} \mathrm{C}$ for ash (AOAC 923.03), defatting in Soxhlet apparatus using hexane for crude lipids (AOAC 920.39), digestion with $\mathrm{NaOH}$ and $\mathrm{H}_{2} \mathrm{SO}_{4}$ for crude fibre (AOAC 962.09) and microKjeldahl method for crude protein (AOAC 960.52). For conversion of Nitrogen to crude protein, a conversion factor of 6.25 was used. The carbohydrate content was estimated by difference of protein, fibre, ash, fat and 100. Energy was calculated using Atwater energy conversion factors of $4.0,4.0$ and $9.0 \mathrm{~kJ} / \mathrm{g}$, for protein, carbohydrate and fat, respectively. Proximate composition was determined using dried samples. Values are presented as $\mathrm{g} / 100 \mathrm{~g}$ on dry weight basis.

\subsubsection{Mineral composition}

Calcium, iron and zinc contents were determined by first digesting $1 \mathrm{~g}$ of sample using $25 \mathrm{ml}$ diacid mixture $\left(\mathrm{HNO}_{3} / \mathrm{HClO}_{4}: 5 /\right.$ $1, \mathrm{v} / \mathrm{v}$ ) after which the digested solution was filtered through Whatman no. 42 filter paper. Volume of the solution was made up to $50 \mathrm{ml}$ and then the mineral content was determined by Atomic Absorption Spectrophotometer 2380, Perkin-Elmer (Waltham, USA) using the method of Lindsey and Norwell (1969).

\subsubsection{In vitro protein and starch digestibility}

In vitro protein digestibility was determined by the method of Mertz, Kirleis, and Axtell (1983). The method involved treatment of $250 \mathrm{mg}$ sample with $20 \mathrm{ml}$ pepsin reagent $\left(0.1 \mathrm{~mol} / \mathrm{L} \mathrm{KH}_{2} \mathrm{PO}_{4}(\mathrm{pH}\right.$ 2.0) containing $0.2 \mathrm{~g} / 100 \mathrm{~mL}$ pepsin) and then incubating at $37^{\circ} \mathrm{C}$ for $3 \mathrm{~h}$ with constant shaking. The digested protein was then separated by sedimenting residual protein with $5 \mathrm{ml}$ of $50 \mathrm{~g} / 100 \mathrm{~mL}$ trichloroacetic acid and centrifugation at $16,770 \times g$ for $10 \mathrm{~min}$. The Nitrogen content of the supernatant containing digested protein was determined by the microKjeldahl method (AOAC, 1990).

In vitro starch digestibility was assessed by using pancreatic amylase. Twenty-five milligram of the defatted sample was dispersed in $1 \mathrm{ml} 0.2 \mathrm{~mol} / \mathrm{L}$ phosphate buffer ( $\mathrm{pH} \mathrm{6.9)}$. Half a millilitre of pancreatic amylase was added and then the suspension was incubated at $37{ }^{\circ} \mathrm{C}$ for $2 \mathrm{~h}$. After incubation, $3 \mathrm{ml}$ of 3, 5-dinitrosalicyclic acid reagent was quickly added and then heated for 5 min in a boiling water bath. Next, the mixture was cooled and distilled water was added to get $25 \mathrm{ml}$. This solution was filtered and liberated maltose was measured colorimetrically at $550 \mathrm{~nm}$. Maltose was used as standard and the values are expressed as mg of maltose liberated per gram of sample (Singh, Kherdekar, \& Jambunathan, 1982).

\subsubsection{In vitro mineral accessibility}

In vitro iron accessibility was determined by digesting the sample with a single enzyme method as described by Rao and Prabhavathi (1978). This method is convenient, requires a minimum of chemicals, and is well suited for comparative purposes. Obviously, it does not necessarily predict exactly what will happen in-vivo, but neither do the more sophisticated in-vitro approaches.

The method involved incubation of $2 \mathrm{~g}$ of powdered sample with $25 \mathrm{ml} 0.5 \mathrm{~g} / 100 \mathrm{~mL}$ pepsin in $0.1 \mathrm{~mol}$ equi/L $\mathrm{HCl}$ solution in a water bath of $37^{\circ} \mathrm{C}$ for $90 \mathrm{~min}$, after adjusting the $\mathrm{pH}$ to 1.3 using $\mathrm{HCl}$. The mixture was then centrifuged at $1000 \times \mathrm{g}$ for $45 \mathrm{~min}$ and the supernatant was filtered through Whatman no. 44 filter paper. Iron in the filtrate was determined according to the AOAC (1995) method by treating with $1 \mathrm{ml}$ hydroxylamine hydrochloride solution and $5 \mathrm{ml}$ acetate buffer solution and then reacted with $\alpha, \alpha^{\prime}$ dipyridyl to yield colour which was read at $510 \mathrm{~nm}$. 
In vitro zinc and calcium accessibility were assessed with the multiple enzyme method of Kim and Zemel (1986). The method involved hydration of $2 \mathrm{~g}$ sample with $3 \mathrm{ml}$ distilled water. Hydrated samples were then treated with $20 \mathrm{ml}$ pepsin solution $(0.1 \mathrm{~g} / 100 \mathrm{~mL}$ pepsin in $0.1 \mathrm{~mol}$ equi/ $\mathrm{L} \mathrm{HCl}$ solution). Next the $\mathrm{pH}$ was adjusted to 1.5 followed by incubation at $37^{\circ} \mathrm{C}$ for $1 \mathrm{~h}$ in a controlled temperature chamber cum shaker (BTI-100B, Biotechnologies Inc., New Delhi). After incubation the $\mathrm{pH}$ was raised to 6.8 with $\mathrm{NaOH}$ and $2.5 \mathrm{ml}$ of a suspension containing $0.5 \mathrm{~g} / 100 \mathrm{~mL}$ pancreatin and $5 \mathrm{~g} / 100 \mathrm{~mL}$ bile was added and again incubated for $1 \mathrm{~h}$ at $37{ }^{\circ} \mathrm{C}$ in the controlled temperature chamber cum shaker. Next, the volume was increased to $50 \mathrm{ml}$ with distilled water and immediately centrifuged at $1000 \times \mathrm{g}$ for $45 \mathrm{~min}$ at $5{ }^{\circ} \mathrm{C}$. Supernatants were removed and again centrifuged at $28,350 \times \mathrm{g}$ for $45 \mathrm{~min}$ at $5{ }^{\circ} \mathrm{C}$. The supernatant was digested with diacid mixture $\left(\mathrm{HNO}_{3} /\right.$ $\mathrm{HClO}_{4}: 5 / 1, \mathrm{v} / \mathrm{v}$ ) and then soluble calcium and zinc were determined by an Atomic Absorption Spectrophotometer 2380, Perkin-Elmer (Waltham, USA) using the method of Lindsey and Norwell (1969). Lanthanum chloride was added during the determination according to Vaessen and Van de Kamp (1990).

\subsubsection{Phytic acid and polyphenol content}

Phytic acid (PA) was estimated colorimetrically by the method of Davies and Reid (1979), by incubating $500 \mathrm{mg}$ of sample with $20 \mathrm{ml}$ of $0.5 \mathrm{~mol} / \mathrm{L} \mathrm{HNO}_{3}$ for $3 \mathrm{~h}$ with continuous shaking. The suspension was then filtered through Whatman no. 1 filter paper. One millilitre of this suspension was made up to $1.4 \mathrm{ml}$ using distilled water and then mixed with $1 \mathrm{ml}$ ferric ammonium sulphate solution containing $50 \mu \mathrm{g}$ of $\mathrm{Fe}$. The test tube containing this suspension was placed in boiling water for $20 \mathrm{~min}$. Next, the suspension was cooled to room temperature and $5 \mathrm{ml}$ iso-amyl alcohol was added followed by $0.1 \mathrm{ml}$ ammonium thiocyanate solution $(100 \mathrm{~g} / \mathrm{l})$. The content was mixed well, and centrifuged at $1000 \times \mathrm{g}$ for $10 \mathrm{~min}$. Colour intensity in alcohol was read at $465 \mathrm{~nm}$ using a spectrophotometer (BTI-1100, Biotechnologies Inc., New Delhi, India). For phytic acid determinations, phytic acid sodium salt hydrate (Sigma, P0109) was used for calibration purposes.

Total polyphenols were extracted from $500 \mathrm{mg}$ of defatted sample by refluxing with $50 \mathrm{ml}$ methanol containing $1 \mathrm{~g} / 100 \mathrm{~mL}$ $\mathrm{HCl}$ for $4 \mathrm{~h}$. The extract was concentrated by evaporating methanol on a boiling water bath and brought to $25 \mathrm{ml}$ with methanol-HCl solution (Singh \& Jambunathan, 1981). Half a millilitre of extract was made up to $8.5 \mathrm{ml}$ with distilled water, mixed with $0.5 \mathrm{ml}$ Folin Denis reagent and shaken. After $3 \mathrm{~min}, 1 \mathrm{ml}$ of saturated sodium carbonate was added, followed by shaking. After an h, the absorbance was read at $725 \mathrm{~nm}$. Calculations were done using absorbance and expressed as tannic acid equivalent (Swain \& Hills, 1956).
The PA:Zn, PA:Ca and PA:Fe molar ratios were calculated using the method of Wyatt and Triana-Tejas (1994).

\subsection{Statistical analysis}

Three samples of each mung bean variety were analysed. Mean \pm standard deviation values were calculated. Comparison of means was performed by one way analysis of variance (ANOVA) followed by Tukey multiple comparison test. Significance was accepted at $P<0.05$ (Panse \& Sukhatme, 1961). Pearson linear correlation coefficients were determined to relate the nutrient digestibility and accessibility with concentrations of anti-nutritional factors. All statistical analyses were performed with PASW Statistics (Version 18.0.2).

\section{Results and discussion}

\subsection{Proximate composition}

Crude protein contents were significantly different $(P<0.05)$ among the mung bean varieties (Table 2 ). However, they all fall within the range of data published elsewhere for mung bean (Kochhar \& Hira, 1997; Lotika \& Bains, 2007). This implies that the newly bred varieties are not necessarily better suppliers of protein than the established varieties, which is supported by the fact that even higher protein contents, i.e. $26.9 \mathrm{~g} / 100 \mathrm{~g}$ (Grewal \& Jood, 2009) and $27.7 \mathrm{~g} / 100 \mathrm{~g}$ (Ghavidel \& Prakash, 2007) have been reported in mung bean. Moreover, crude protein may contain nutritionally less important non-protein nitrogen. Therefore, varieties with a higher content of crude protein may not necessarily have a better protein quality. The crude lipid contents did not differ significantly $(P<0.05)$ among the varieties and were within normal ranges as published elsewhere, with the highest concentration $(1.3 \mathrm{~g} / 100 \mathrm{~g})$ found in MH 564. The ash contents of the mung bean varieties ranged from 3.1 to $4.1 \mathrm{~g} / 100 \mathrm{~g}$ dry weight which is also within the range of other published values (Lin \& Lai, 2006). MH 560 had the highest ash content. In contrast, MH 125 had highest content of accessible minerals. This could be due to the presence of lower concentrations of anti-nutritional factors in the latter variety. Crude fibre contents in the mung bean varieties were not different from values reported elsewhere (Lotika \& Bains, 2007). The tested varieties could be distinguished into groups of similar nutrient composition. MH 125 and MH 539 had the highest crude protein, whereas MH 124, MH 421 and MH 560 contained the least crude protein. Among newly bred varieties, crude fibre was highest in $\mathrm{MH}$ 125 with considerable amounts present in MH 124, MH 421 and MH 564. Among the established varieties, the highest crude fibre

Table 2

Proximate composition of newly bred and established mung bean varieties.

\begin{tabular}{|c|c|c|c|c|c|c|c|c|}
\hline Mung bean varieties & & Moisture & Crude protein & Crude fat & Crude fibre & Ash & Carbohydrate* & Energy** \\
\hline \multirow[t]{3}{*}{ Established varieties } & Asha & $9.2 \pm 0.2^{\mathrm{de}}$ & $20.0 \pm 0.50^{\mathrm{bc}}$ & $1.32 \pm 0.09^{a}$ & $4.2 \pm 0.10^{\mathrm{ab}}$ & $3.21 \pm 0.10^{\mathrm{abcd}}$ & $71.3 \pm 0.5^{\mathrm{de}}$ & $1578 \pm 4.0$ \\
\hline & Muskan & $9.7 \pm 0.0^{\text {cde }}$ & $22.1 \pm 0.20^{\text {def }}$ & $1.22 \pm 0.1^{\mathrm{a}}$ & $5.2 \pm 0.17^{\mathrm{d}}$ & $3.27 \pm 0.23^{\mathrm{bcd}}$ & $68.2 \pm 0.4^{\mathrm{abc}}$ & $1557 \pm 3.2$ \\
\hline & Satya & $8.7 \pm 0.2^{\mathrm{bc}}$ & $22.8 \pm 0.10^{f}$ & $1.31 \pm 0.1^{\mathrm{a}}$ & $4.2 \pm 0.09^{\mathrm{ab}}$ & $2.79 \pm 0.26^{\mathrm{a}}$ & $68.9 \pm 0.3^{\mathrm{abc}}$ & $1585 \pm 3.0$ \\
\hline \multirow[t]{7}{*}{ Newly bred varieties } & MH 124 & $8.7 \pm 0.2^{\mathrm{bc}}$ & $19.1 \pm 0.01^{\mathrm{ab}}$ & $1.24 \pm 0.1^{\mathrm{a}}$ & $4.6 \pm 0.29^{\mathrm{bc}}$ & $3.12 \pm 0.11^{\mathrm{abc}}$ & $71.9 \pm 0.3^{\mathrm{ef}}$ & $1571 \pm 3.1$ \\
\hline & MH 125 & $8.3 \pm 0.2^{\mathrm{ab}}$ & $22.9 \pm 0.95^{\mathrm{f}}$ & $1.23 \pm 0.2^{\mathrm{a}}$ & $5.4 \pm 0.19^{d}$ & $3.08 \pm 0.04^{\mathrm{abc}}$ & $67.4 \pm 1.0^{\mathrm{a}}$ & $1557 \pm 6.1$ \\
\hline & MH 318 & $9.7 \pm 0.2^{f}$ & $20.8 \pm 0.08^{\mathrm{bcd}}$ & $1.51 \pm 0.11^{\mathrm{a}}$ & $4.1 \pm 0.09^{\mathrm{a}}$ & $3.65 \pm 0.09^{\mathrm{de}}$ & $69.9 \pm 0.2^{\mathrm{cd}}$ & $1575 \pm 2.7$ \\
\hline & MH 421 & $8.8 \pm 0.1^{\mathrm{cd}}$ & $17.9 \pm 0.10^{\mathrm{a}}$ & $1.16 \pm 0.1^{\mathrm{a}}$ & $4.4 \pm 0.10^{\mathrm{abc}}$ & $3.37 \pm 0.26^{\mathrm{cd}}$ & $73.3 \pm 0.3^{f}$ & $1510 \pm 3.1$ \\
\hline & MH 539 & $8.9 \pm 0.1^{\mathrm{cd}}$ & $22.7 \pm 1.05^{\mathrm{ef}}$ & $1.36+0.19^{\mathrm{a}}$ & $4.7 \pm 0.10^{c}$ & $3.35 \pm 0.13^{\mathrm{bcd}}$ & $67.9 \pm 1.1^{\mathrm{ab}}$ & $1568 \pm 6.6$ \\
\hline & MH 560 & $8.0 \pm 0.1^{\mathrm{a}}$ & $19.6 \pm 0.26^{\mathrm{abc}}$ & $1.48 \pm 0.4^{\mathrm{a}}$ & $5.2 \pm 0.10^{\mathrm{d}}$ & $4.08 \pm 0.01^{\mathrm{e}}$ & $69.7 \pm 0.5^{\mathrm{bcd}}$ & $1550 \pm 5.0$ \\
\hline & MH 564 & $9.5 \pm 0.2^{\mathrm{ef}}$ & $21.1 \pm 1.0^{\text {cde }}$ & $1.64 \pm 0.1^{\mathrm{a}}$ & $4.5 \pm 0.09^{\mathrm{abc}}$ & $2.89 \pm 0.10^{\mathrm{ab}}$ & $69.9 \pm 1.0^{\mathrm{cd}}$ & $1585 \pm 6.1$ \\
\hline
\end{tabular}

Values (g/100 g) are expressed as Mean \pm Standard Deviation $(n=3)$ on dry matter basis (except for moisture).

Means in the same column with the different superscripts are significantly different at $P<0.05$.

${ }^{*}$ Calculated by difference from protein, fat, ash, fibre and dry matter.

${ }^{* *}$ Energy $(\mathrm{kJ} / 100 \mathrm{~g})=($ Fat $(\mathrm{g}) \times 9.0+$ Protein $(\mathrm{g}) \times 4.0+$ Carbohydrate $(\mathrm{g}) \times 4.0) \times 4.184$. 
Table 3

Mineral composition of newly bred and established mung bean varieties.

\begin{tabular}{|c|c|c|c|c|c|c|c|}
\hline Mung bean varieties & & Iron & Zinc & Calcium & Magnesium & Sodium & Potassium \\
\hline \multirow[t]{3}{*}{ Established varieties } & Asha & $3.9 \pm 0.06^{c}$ & $1.2 \pm 0.03^{\mathrm{a}}$ & $103 \pm 1.6^{\mathrm{d}}$ & $157 \pm 2.4^{\mathrm{d}}$ & $9.4 \pm 0.3^{\mathrm{ab}}$ & $363 \pm 1.5^{\mathrm{a}}$ \\
\hline & Muskan & $3.6 \pm 0.15^{a}$ & $1.7 \pm 0.05^{\mathrm{cd}}$ & $98 \pm 0.4^{\mathrm{c}}$ & $137 \pm 3.0^{\mathrm{b}}$ & $10.6 \pm 0.4^{\mathrm{cd}}$ & $403 \pm 1.7^{\mathrm{e}}$ \\
\hline & Satya & $3.9 \pm 0.10^{c}$ & $1.3 \pm 0.05^{\mathrm{ab}}$ & $95 \pm 1.5^{c}$ & $129 \pm 3.0^{\mathrm{a}}$ & $8.7 \pm 0.4^{\mathrm{a}}$ & $389 \pm 3.1^{c}$ \\
\hline \multirow[t]{7}{*}{ Newly bred varieties } & MH 124 & $3.9 \pm 0.03^{c}$ & $1.4 \pm 0.05^{\mathrm{ab}}$ & $97 \pm 3.0^{c}$ & $158 \pm 1.1^{\mathrm{d}}$ & $8.5 \pm 0.4^{\mathrm{a}}$ & $380 \pm 1.3^{\mathrm{b}}$ \\
\hline & MH 125 & $4.6 \pm 0.10^{\mathrm{d}}$ & $1.7 \pm 0.14^{\mathrm{d}}$ & $114 \pm 1.0^{\mathrm{e}}$ & $166 \pm 1.6^{\mathrm{e}}$ & $13.2 \pm 0.3^{\mathrm{f}}$ & $411 \pm 1.2^{\mathrm{fg}}$ \\
\hline & MH 318 & $4.4 \pm 0.14^{\mathrm{d}}$ & $1.5 \pm 0.05^{\mathrm{abc}}$ & $90 \pm 0.6^{\mathrm{b}}$ & $156 \pm 1.6^{\mathrm{d}}$ & $10.4 \pm 0.3^{\mathrm{bc}}$ & $407 \pm 2.5^{\mathrm{eg}}$ \\
\hline & MH 421 & $4.4 \pm 0.09^{d}$ & $2.1 \pm 0.14^{\mathrm{e}}$ & $104 \pm 1.6^{\mathrm{d}}$ & $147 \pm 1.4^{c}$ & $10.0 \pm 0.2^{\mathrm{bc}}$ & $398 \pm 1.1^{\mathrm{d}}$ \\
\hline & MH 539 & $3.4 \pm 0.01^{\mathrm{a}}$ & $1.3 \pm 0.02^{\mathrm{a}}$ & $81 \pm 1.2^{\mathrm{a}}$ & $159 \pm 1.0^{\mathrm{d}}$ & $11.7 \pm 0.4^{\mathrm{de}}$ & $382 \pm 1.6^{\mathrm{b}}$ \\
\hline & MH 560 & $3.4 \pm 0.15^{\mathrm{a}}$ & $1.4 \pm 0.04^{\mathrm{ab}}$ & $105 \pm 0.9^{d}$ & $150 \pm 1.4^{\mathrm{c}}$ & $11.8 \pm 0.5^{\mathrm{e}}$ & $414 \pm 1.1^{\mathrm{f}}$ \\
\hline & MH 564 & $3.8 \pm 0.13^{b c}$ & $1.5 \pm 0.13^{\mathrm{cd}}$ & $94 \pm 2.3^{c}$ & $157 \pm 2.3^{d}$ & $8.8 \pm 0.3^{\mathrm{a}}$ & $394 \pm 1.6^{\mathrm{d}}$ \\
\hline
\end{tabular}

Values (mg/100 g dry matter) are expressed as Mean \pm Standard Deviation $(n=3)$.

Means in the same column with the different superscripts are significantly different at $P<0.05$.

was found in Muskan (5.2 g/100 g), which is comparable to that of newly bred variety MH 125 (5.4 g/100 g).

\subsection{Mineral content}

The mineral concentrations are presented in Table 3. Although there are statistically significant differences between mineral levels among the varieties, their levels are within the expected range for mung bean (Jood, Bishnoi, \& Sehgal, 1998). The significant difference in the mineral content of the varieties may have several reasons, but are most likely due to the ability of the root to absorb minerals from the soil, the physiological role of minerals in the plant and the translocation of minerals in the plant as suggested by Frossard et al. (2000). These authors also concluded that the mineral uptake mechanism varies among varieties, depending on root mycorrhiza and plant architecture. The cumulative mineral contents represent only about $30 \%$ of the total ash content; this is due to the fact that the minerals are determined as elements and the ash contains their salts. Ash may also contain salts of which the elements were not determined.

MH 125 had the highest content of iron, calcium, magnesium and sodium and might thus be of nutritional interest. In addition, MH 421 had the highest zinc content and considerable amounts of iron, calcium and magnesium.

The presence of large amounts of particular minerals can influence the absorption of others. Competition can take place, i.e. a higher amount of calcium and magnesium compared to iron and zinc may reduce their accessibility, but may also be favourable when such major minerals occupy binding sites on mineral chelating compounds such as phytic acid and polyphenols. All varieties contained considerable amounts of magnesium, and higher amounts of iron and zinc than found in wheat and rice (Srikumar, 1993). Therefore, mung bean may contribute to mineral intake when eaten with cereals, particularly products of refined cereal flour. However, the favourable mineral content of mung beans does not necessarily result in high dietary mineral intake. Optimum food processing methods are essential to avoid losses and enhance the accessibility of minerals for adequate intake.

\subsection{Phytic acid and polyphenols}

Phytic acid and polyphenol contents are presented in Table 4. Phosphorus in mung bean is mainly stored in the form of phytic acid. The phytic acid content of the tested varieties was within the range reported elsewhere (Jood et al., 1998; Kataria, Chauhan, \& Punia, 1989). However, some authors reported considerably lower phytate contents, i.e. $236 \mathrm{mg} / 100 \mathrm{~g}$ (Lestienne, Verniere, Mouquet, Picq, \& Treche, 2005) and $201.3 \mathrm{mg} / 100 \mathrm{~g}$ (Philip \& Prema, 1998). The differences from previous studies could be due to the method of analysis. Lestienne et al. (2005), for instance, determined phytate in mung bean by the estimation of the myo-inositol hexaphosphate content obtained by anion exchange HPLC separation, which is a more specific method for inositol-hexa-phosphate than the method used by us, which determines all inositol phosphates. However, much higher phytic acid contents (1020-1480 mg/100 g) have also been reported in mung bean (Chitra, Vimala, Singh, \& Geervani, 1995). Phytic acid molecules are negatively charged at physiological $\mathrm{pH}$ and bind with divalent ions making them unavailable for absorption. Nutritionally there is no significant variation in the phytic acid as its amount is sufficient to bind the minerals to form indigestible complexes.

Among the selected mung bean varieties, polyphenol contents were highest in MH 318 and lowest in $\mathrm{MH} \mathrm{125.} \mathrm{The} \mathrm{polyphenol}$ concentrations in the tested varieties are within the normal range published elsewhere (Jood et al., 1998; Kataria et al., 1989). This range $(270.5-353.0 \mathrm{mg} / 100 \mathrm{~g}$ ) is genetically determined

Table 4

Phytic acid (PA), polyphenols \& molar ratios of phytic acid to minerals of newly bred and established mung bean varieties.

\begin{tabular}{|c|c|c|c|c|c|c|c|}
\hline Mung bean varieties & & $\begin{array}{l}\text { Phytic acid } \\
\text { (mg/100 g) }\end{array}$ & $\begin{array}{l}\text { Polyphenols } \\
\text { (mg/100 g) }\end{array}$ & $\begin{array}{l}\text { PA:Fe } \\
\text { molar ratio }\end{array}$ & $\begin{array}{l}\text { PA:Zn } \\
\text { molar ratio }\end{array}$ & $\begin{array}{l}\mathrm{PA}: \mathrm{Ca} \\
\text { molar ratio }\end{array}$ & $\begin{array}{l}\text { PA:Mg } \\
\text { molar ratio }\end{array}$ \\
\hline \multirow[t]{3}{*}{ Established varieties } & Asha & $748 \pm 4.6^{\mathrm{abc}}$ & $353.0 \pm 3.5^{\mathrm{de}}$ & $16 \pm 0.3$ & $62 \pm 1.5$ & $0.44 \pm 0.01$ & $0.17 \pm 0.002$ \\
\hline & Muskan & $734 \pm 11.0^{\mathrm{ab}}$ & $317.2 \pm 4.2^{c}$ & $17 \pm 0.8$ & $46 \pm 1.6$ & $0.46 \pm 0.01$ & $0.20 \pm 0.005$ \\
\hline & Satya & $765 \pm 7.5^{\mathrm{cd}}$ & $272.7 \pm 3.5^{\mathrm{a}}$ & $17 \pm 0.5$ & $58 \pm 2.1$ & $0.49 \pm 0.01$ & $0.21 \pm 0.005$ \\
\hline \multirow[t]{7}{*}{ Newly bred varieties } & MH 124 & $789 \pm 12.2^{\mathrm{de}}$ & $325.2 \pm 3.2^{\mathrm{c}}$ & $17 \pm 0.3$ & $58 \pm 2.1$ & $0.50 \pm 0.02$ & $0.18 \pm 0.003$ \\
\hline & MH 125 & $726 \pm 6.8^{\mathrm{a}}$ & $270.5 \pm 5.0^{\mathrm{a}}$ & $14 \pm 0.3$ & $42 \pm 3.4$ & $0.39 \pm 0.00$ & $0.16 \pm 0.002$ \\
\hline & MH 318 & $807 \pm 8.5^{\mathrm{e}}$ & $363.9 \pm 5.4^{\mathrm{e}}$ & $16 \pm 0.5$ & $55 \pm 2.0$ & $0.55 \pm 0.01$ & $0.19 \pm 0.003$ \\
\hline & MH 421 & $765 \pm 9.5^{\mathrm{cd}}$ & $293.4 \pm 5.0^{\mathrm{b}}$ & $15 \pm 0.4$ & $35 \pm 0.5$ & $0.45 \pm 0.01$ & $0.19 \pm 0.003$ \\
\hline & MH 539 & $786 \pm 11.5^{\text {de }}$ & $352.7 \pm 5.5^{\text {ade }}$ & $20 \pm 0.3$ & $61 \pm 1.3$ & $0.60 \pm 0.01$ & $0.18 \pm 0.003$ \\
\hline & MH 560 & $806 \pm 9.3^{\mathrm{e}}$ & $345.9 \pm 2.1^{\mathrm{d}}$ & $20 \pm 0.9$ & $62 \pm 2.0$ & $0.47 \pm 0.01$ & $0.20 \pm 0.003$ \\
\hline & MH 564 & $760 \pm 4.6^{\mathrm{bc}}$ & $347.2 \pm 3.0^{\mathrm{d}}$ & $17 \pm 0.6$ & $49 \pm 4.3$ & $0.49 \pm 0.01$ & $0.18 \pm 0.003$ \\
\hline
\end{tabular}

Values are expressed as Mean \pm Standard Deviation $(n=3)$ on dry matter basis.

Means in the same column with the different superscripts are significantly different at $P<0.05$. 


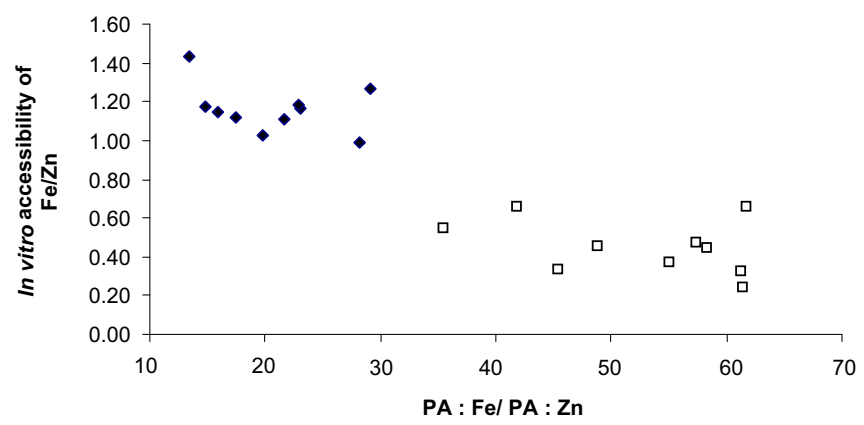

Fig. 1. In vitro accessibility of $\mathrm{Fe}$ and $\mathrm{Zn}$ as affected by $\mathrm{PA}: \mathrm{Fe}$ and $\mathrm{PA}: \mathrm{Zn}$ molar ratios, respectively. $\bullet$ PA:Fe, $\square$ PA:Zn. PA: phytic acid, Fe: iron, Zn: zinc.

(Dicko et al., 2002). Polyphenols are mainly present in the seed coat (Barroga, Laurena, \& Mendoza, 1985); they are present in higher amounts in coloured or darker legume varieties (Salunkhe, Jadhav, Kadam, \& Chavan, 1982). The newly bred varieties tested still contain considerable polyphenol concentrations, and as such they do not represent an improvement compared to the established varieties. Polyphenols in mung bean are considered as anti-nutrient compounds with respect to mineral accessibility, but may also have positive health benefits (Randhir, Lin, \& Shetty, 2004).

Phytic acid to mineral molar ratios (Table 4) are used as an indicator for the bioaccessibility of minerals. The average PA:Fe and $P A: Z n$ of the varieties are 16.8 and 52.7 respectively. This is much higher than the values of 2.8 and 8.2 respectively, as reported by Lestienne et al. (2005). The PA:Fe molar ratio in mung bean is lower than in cereals like maize (34.4), sorghum (22.8) (Lestienne et al., 2005) and rice (49.5) (Liang, Han, Han, Nout, \& Hamer, 2007), but higher than in soya bean (10.1) (Lestienne et al., 2005). The PA:Zn ratio in mung bean is lower than in sorghum (62.8) (Lestienne et al., 2005), but higher than in rice (42.0) (Liang et al., 2007) and maize (40.6) (Lestienne et al., 2005).

Critical values of molar ratios of phytic acid to a mineral for adequate mineral absorption have been reported as $<0.24$ for phytate/calcium (Morris \& Ellis, 1980), <1 for phytate:iron (Hallberg, Brune, \& Rossander, 1989), $<10$ for phytate:zinc (Morris \& Ellis, 1980) and $<3.5$ for phytate $\times$ calcium:zinc (Fordyce, Forbes, Robbins, \& Erdman Jr., 1987). High PA:Zn and PA:Fe ratios indicate poor iron and zinc accessibility. These ratios vary among mung bean varieties, showing that varieties with lower phytic acid to mineral ratios have comparatively higher mineral accessibility. The values of PA:Ca are much lower than PA:Fe and PA:Zn due to the presence of higher amounts of calcium in the mung bean varieties. In the selected varieties it seems that in vitro iron and zinc accessibility was not affected by PA:Fe and PA:Zn (Fig. 1) in the tested

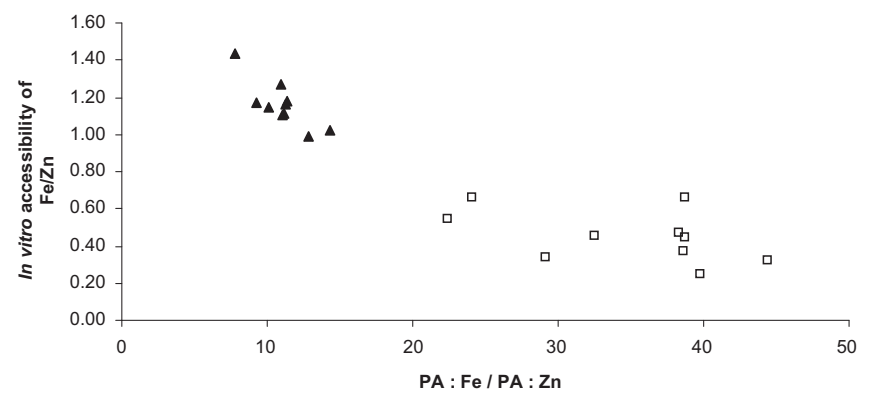

Fig. 2. In vitro accessibility of $\mathrm{Fe}$ and $\mathrm{Zn}$ as affected by PA:Fe and PA:Zn molar ratios respectively (as calculated by phytic acid available after binding with all calcium present). $\Delta \mathrm{Fe}, \square \mathrm{Zn}$. PA: phytic acid, Fe: iron, Zn: zinc.

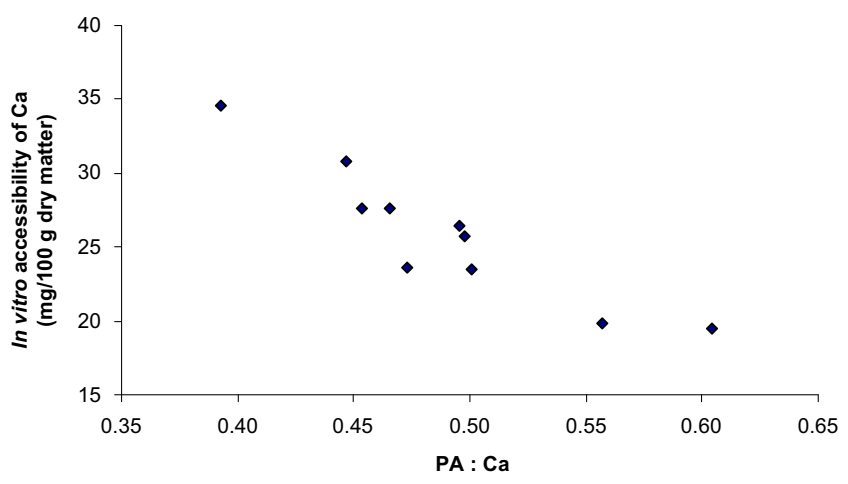

Fig. 3. In vitro calcium accessibility as affected by PA:Ca molar ratio. PA: phytic acid, Ca: calcium.

range. The divalent calcium cation, because of its higher concentration and stronger affinity for phytate, may exert a sparing action for iron and zinc by forming phytate-calcium complexes. However, when assuming that all calcium would be complexed with PA, there would still remain enough phytic acid to make insoluble complexes with iron and zinc. Fig. 2 shows that in vitro iron and zinc accessibility did not improve as a function of PA:Fe (9.3-12.9) and PA:Zn (22.7-39.8) ratios calculated with amounts of phytic acid left after binding with all calcium. This suggests that the molar ratios PA:Fe and PA:Zn were still too high to allow a better accessibility of Fe and Zn. Fig. 3 shows that PA:Ca is one of the possible factors affecting the in vitro calcium accessibility. Calcium can also form calciumzinc-phytate complexes, which have a lower solubility product than phytic acid-zinc or phytic acid-calcium complexes (Fordyce et al., 1987). The magnesium content in the varieties is even higher than of calcium, which indicates possibilities of formation of magnesium-phytate complexes and thus making phytate unavailable for iron and zinc. But, as indicated in Fig. 4, it seems that the concentration of magnesium is not determining iron and zinc accessibility, which is also supported by the in vivo studies that suggested that the concentration of magnesium does not have a significant impact on zinc bioavailability as compared to the concentration of calcium (Forbes, Parker, \& Erdman Jr., 1984). None of the phytic acid to mineral ratios could explain the lower mineral accessibility and thus predict mineral bioavailability. This may be because the phytate concentrations were excessively high and also because mineral ratios depend on other factors like $\mathrm{pH}$, temperature, ionic strength and presence of other mineral ions.

In terms of improvement in varieties through breeding techniques, MH 125 seems to be improved nutritionally as it had the lowest phytate to mineral ratios, which indicate higher mineral bioavailability. However, agronomically there is no significant

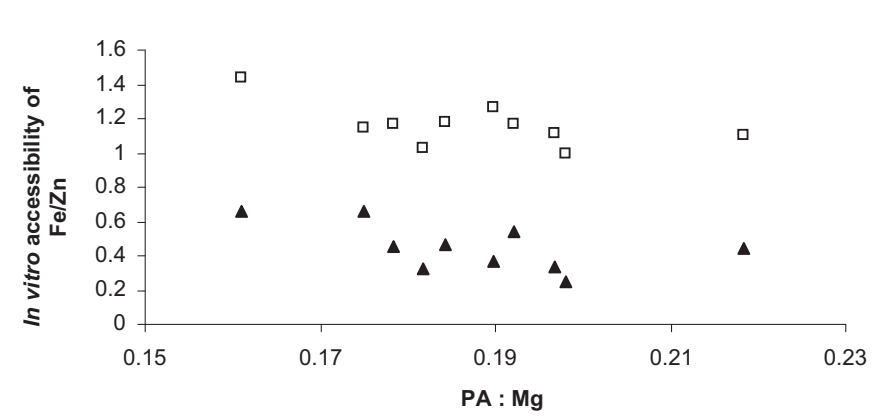

Fig. 4. In vitro accessibility of Fe and $\mathrm{Zn}$ as affected by PA:Mg molar ratio. $\boldsymbol{\mathrm { Zn }}, \square$ Fe. PA: phytic acid, Fe: iron, $\mathrm{Zn}$ : zinc, Mg: magnesium. 
Table 5

In vitro nutrient digestibility and mineral accessibility of newly bred and established mung bean varieties.

\begin{tabular}{|c|c|c|c|c|c|c|c|c|c|}
\hline \multirow{2}{*}{$\begin{array}{l}\text { Mung bean } \\
\text { varieties }\end{array}$} & & \multirow{2}{*}{$\begin{array}{l}\text { In vitro protein } \\
\text { digestibility } \\
(\mathrm{g} / 100 \mathrm{~g} \mathrm{dw})\end{array}$} & \multirow{2}{*}{$\begin{array}{l}\text { In vitro starch } \\
\text { digestibility } \\
\text { (mg maltose } \\
\text { released/g) }\end{array}$} & \multicolumn{2}{|c|}{ In vitro iron accessibility } & \multicolumn{2}{|c|}{ In vitro zinc accessibility } & \multicolumn{2}{|c|}{ In vitro calcium accessibility } \\
\hline & & & & $\mathrm{mg} / 100 \mathrm{~g}$ & $\mathrm{~g} / 100 \mathrm{~g}$ & $\mathrm{mg} / 100 \mathrm{~g}$ & $\mathrm{~g} / 100 \mathrm{~g}$ & $\mathrm{mg} / 100 \mathrm{~g}$ & $\mathrm{~g} / 100 \mathrm{~g}$ \\
\hline \multirow{3}{*}{$\begin{array}{r}\text { Established } \\
\text { varieties }\end{array}$} & Asha & $63 \pm 0.3^{e}$ & $26.5 \pm 0.23^{\mathrm{d}}$ & $1.15 \pm 0.03^{\mathrm{ab}}$ & 28.9 & $0.65 \pm 0.02^{\mathrm{e}}$ & 29.1 & $30.8 \pm 0.29^{\mathrm{e}}$ & 29.5 \\
\hline & Muskan & $63 \pm 0.7^{\mathrm{e}}$ & $24.4 \pm 0.39^{c}$ & $1.12 \pm 0.08^{\mathrm{ab}}$ & 31.4 & $0.33 \pm 0.03^{\mathrm{b}}$ & 23.1 & $27.6 \pm 0.45^{\mathrm{d}}$ & 28.3 \\
\hline & Satya & $65 \pm 0.6^{\mathrm{ef}}$ & $24.6 \pm 0.54^{c}$ & $1.10 \pm 0.02^{\mathrm{ab}}$ & 28.5 & $0.44 \pm 0.01^{\mathrm{c}}$ & 23.0 & $26.5 \pm 0.09^{\mathrm{cd}}$ & 27.8 \\
\hline \multirow{7}{*}{$\begin{array}{c}\text { Newly bred } \\
\text { varieties }\end{array}$} & MH 124 & $58 \pm 0.3^{\mathrm{cd}}$ & $22.5 \pm 0.26^{\mathrm{b}}$ & $1.19 \pm 0.14^{\mathrm{abc}}$ & 30.2 & $0.47 \pm 0.03^{c}$ & 25.0 & $23.5 \pm 0.4^{\mathrm{b}}$ & 24.4 \\
\hline & MH 125 & $67 \pm 0.2^{\mathrm{f}}$ & $28.6 \pm 0.15^{\mathrm{e}}$ & $1.40 \pm 0.12^{\mathrm{c}}$ & 31.4 & $0.66 \pm 0.02^{\mathrm{e}}$ & 28.1 & $34.6 \pm 0.34^{\mathrm{e}}$ & 30.5 \\
\hline & MH 318 & $54 \pm 0.7^{\mathrm{ab}}$ & $19.6 \pm 0.57^{\mathrm{a}}$ & $1.27 \pm 0.04^{\mathrm{bc}}$ & 29.1 & $0.37 \pm 0.01^{\mathrm{b}}$ & 23.3 & $19.9 \pm 0.19^{\mathrm{a}}$ & 22.2 \\
\hline & MH 421 & $59 \pm 0.5^{\mathrm{d}}$ & $21.8 \pm 0.49^{b}$ & $1.17 \pm 0.15^{\mathrm{ab}}$ & 26.7 & $0.54 \pm 0.01^{\mathrm{d}}$ & 26.2 & $27.6 \pm 0.33^{\mathrm{d}}$ & 26.2 \\
\hline & MH 539 & $56 \pm 1.1^{\mathrm{bc}}$ & $21.6 \pm 0.26^{b}$ & $1.02 \pm 0.01^{\mathrm{a}}$ & 30.5 & $0.32 \pm 0.01^{\mathrm{b}}$ & 26.1 & $19.5 \pm 0.95^{\mathrm{a}}$ & 24.5 \\
\hline & MH 560 & $53 \pm 1.1^{\mathrm{a}}$ & $19.6 \pm 0.72^{\mathrm{a}}$ & $0.99 \pm 0.08^{\mathrm{a}}$ & 29.0 & $0.24 \pm 0.01^{\mathrm{a}}$ & 20.3 & $23.6 \pm 0.06^{\mathrm{b}}$ & 22.4 \\
\hline & MH 564 & $58 \pm 0.4^{\mathrm{d}}$ & $22.5 \pm 0.26^{\mathrm{b}}$ & $1.16 \pm 0.03^{\mathrm{ab}}$ & 30.8 & $0.45 \pm 0.02^{c}$ & 25.1 & $25.7 \pm 0.22^{c}$ & 27.5 \\
\hline
\end{tabular}

Values are expressed as Mean \pm Standard Deviation $(n=3)$ on dry matter basis.

Means in the same column with the different superscripts are significantly different at $P<0.05$.

improvement due to its lower yield as compared to MH 560 and MH 564.

\subsection{In vitro nutrient digestion and mineral accessibility}

In vitro protein digestibility of varieties showed significant diversity ranging from $53.1 \mathrm{~g} / 100 \mathrm{~g}$ dry weight in MH 560 to $67.1 \mathrm{~g} / 100 \mathrm{~g}$ dry weight in MH 125 (Table 5). The remaining protein may be indigestible due to the presence of trypsin inhibitors and hemaglutinins in mung bean, which has been reported as the main reason for lower protein digestibility in legumes (Mubarak, 2005). Negative correlations between phytic acid and in vitro protein digestibility were found $\left(R^{2}=-0.85\right)$ as shown in Fig. 5 . Thus, the presence of different amounts of phytic acid in these varieties might also have caused the variation in in vitro protein digestibility, as phytic acid-mineral complexes bind with peptides to form insoluble phytic acid-mineral-peptide complexes (Bhatia \& Khetarpaul, 2009). Protein digestibility in mung bean has been reported to be lower than that of lentils (Singh \& Jood, 2009).

In vitro starch digestibility was found to be lowest $(19.6 \mathrm{mg}$ maltose released/g) in $\mathrm{MH} 560$ and highest $(28.6 \mathrm{mg}$ maltose released/g) in MH 125 (Table 5). The results of the present study are consistent with that of earlier studies (Grewal \& Jood, 2009; Jood et al., 1998). Except for MH 125, all high yielding newly bred varieties showed considerably lower starch digestibility than the established varieties. There was a negative correlation of in vitro starch digestibility with phytic acid $\left(R^{2}=-0.83\right)$ and polyphenols $\left(R^{2}=-0.47\right)$ as shown in Fig. 5. This difference in starch digestibility among varieties may be due to differences in amounts of

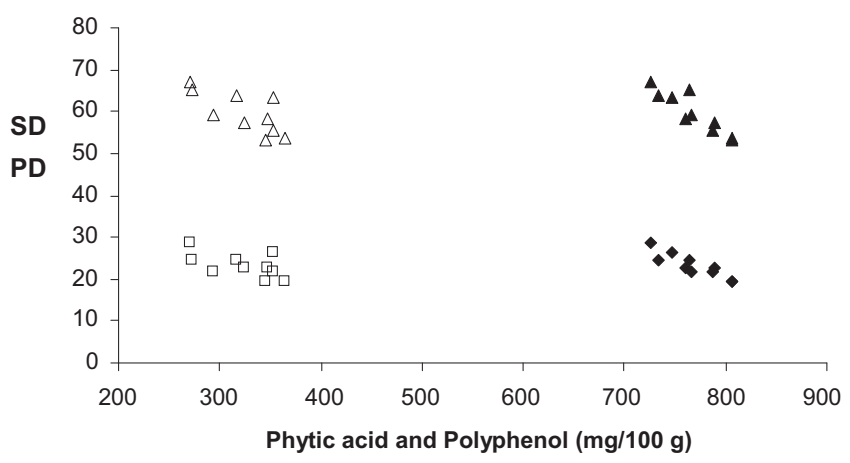

Fig. 5. In vitro Protein and Starch digestibility as a function of phytic acid and polyphenol. SD: starch digestibility (mg maltose released/g dry weight); PD (g/100 g dry weight). Phytic Acid vs. Starch Digestibility, $\square$ Polyphenol vs. Starch Digestibility, $\boldsymbol{\Delta}$ Phytic Acid vs. Protein Digestibility, $\triangle$ Polyphenol vs. Protein Digestibility. anti-nutrient factors like phytic acid (Yoon, Thompson, \& Jenkins, 1983) and polyphenols (Farias et al., 2007) due to their inhibition of amylase. The native starch is present in granules, which are only affected by hydrolytic enzymes if damaged; further processing such as heating may cause gelatinization, and this will increase susceptibility to enzymatic activity. Other food processing methods such as grinding, hydration and disruption of the native granule starch structure have also been found to increase starch digestibility (Bhama \& Sadana, 2004).

In vitro mineral accessibility can be a global index of in vivo mineral bioavailability. Mung bean ( $100 \mathrm{~g}$ ) should cover $12-16 \%$ of iron, $8-14 \%$ of zinc and $20-29 \%$ of calcium according to the recommended daily intake (RDI) based on the total amount of these minerals. However, due to the lower bioavailability it only covers $3.5-5.1 \%$ of iron, $1.6-4.4 \%$ of zinc and $4.9-8.6 \%$ of calcium of the RDI. Mung bean varieties like MH 318, with a high amount of phytic acid, were found to have the lowest amounts of accessible minerals. The values of the present study support those of Jood et al. (1998) in mung bean cultivars. Significant negative correlations of phytic acid and polyphenol were found with in vitro mineral accessibility. The differences in mineral accessibility among varieties may be related to their contents of anti-nutrients such as phytic acid, polyphenols as well as dietary fibre; and to their contents of respective minerals, iron, zinc and calcium. As mung beans do not contain any mineral uptake enhancer such as vitamin $C$, the effects of the anti-nutrients mentioned earlier need to be minimised to achieve a better mineral bioavailability. A possible way to achieve this is by dephytinization. Wet processing such as fermentation and germination was shown to contribute to dephytinization (Hemalatha, Platel, \& Srinivasan, 2007; Lotika \& Bains, 2007; Nout, 2009). Dehulling and cooking can reduce the polyphenol concentrations, thereby increasing the nutritional value of the grain (Madhuri, Pratima, \& Rao, 1996). This also suggests that mung bean products obtained through fermentation, germination and soaking may achieve higher levels of mineral bioavailability.

\section{Conclusion and recommendations}

Farmers are predominantly interested in the agronomic characteristics of their mung bean varieties as this result in higher yields and revenues. However, agricultural extension services should also pay attention to nutritional characteristics of the mung bean varieties.

We recommend that plant breeders should focus on a combination of crop yield, with nutritional value and consumer preference traits. A low phytic acid content may be a desired property from a nutritional point of view, but it may hamper the growth of the plants 
when too low (Coelho et al., 2002). Thus, phytic acid contents need to be reduced by appropriate breeding techniques without compromising seed germination (Bohn, Meyer, \& Rasmussen, 2008), or by processing methods such as fermentation. Another target for plant breeding is to improve the mineral content to enhance micronutrient availability. It should be realized that the investigated cultivars were grown under identical conditions on the same plot and during the same season, so the data presented could only be seen as comparative and not absolute, in the absence of performance data in different locations or seasons. However, from this study we conclude that although the newly bred varieties hold promise for better agronomic yields, their nutritional potential is not better than that of established varieties.

\section{Acknowledgements}

We gratefully acknowledge the financial support from the Department of Biotechnology, Ministry of Science and Technology, Government of India, from Wageningen University through the Interdisciplinary Research and Education Fund (INREF) via the TELFUN programme and from International Foundation of Science (IFS). We thank Professor Ram Kumar of the Department of Plant Breeding of CCS Haryana Agricultural University, Hisar, India, who provided the mung bean varieties under investigation along with the relevant information on status and characteristics of the varieties. We also thank Dr. Neelam Khaterpaul of the Department of Foods and Nutrition of CCS Haryana Agricultural University, Hisar, India and country co-ordinator of the TELFUN programme for her invaluable help.

\section{References}

Abdullah, A., Baldwin, R. E., \& Minor, H. (1984). Germination effects on flatus causing factors and anti-nutrients of mung beans and two strains of smallseeded soybeans. Journal of Food Protection, 47(6), 441-444.

AOAC. (1990). Official methods of analysis. Washington. D.C.: Association of Official Analytical Chemists.

AOAC. (1995). Official methods of analysis. Washington, D.C.: Association of Official Analytical Chemists.

Barroga, C. F., Laurena, A. C., \& Mendoza, E. M. T. (1985). Polyphenols in mung bean (Vigna-Radiata (L) Wilczek) - determination and removal. Journal of Agricultural and Food Chemistry, 33(5), 1006-1009.

Bhama, S., \& Sadana, B. K. (2004). In vitro digestibility and minerals availability from Bengal gram dhal and flour products. Journal of Food Science and Technology, 41(4), 459-461.

Bhatia, A., \& Khetarpaul, N. (2009). Development of an indigenously fermented Indian bread - doli ki roti: effect on phytic acid content and in vitro digestibility of starch and protein. Nutrition and Food Science, 39(4), 330-336.

Binita, R., \& Khetarpaul, N. (1997). Probiotic fermentation: effect on antinutrients and digestibility of starch and protein of indigenously developed food mixture. Nutrition and Health, 11(3), 139-147.

Bisht, I. S., Bhat, K. V., Lakhanpaul, S., Latha, M., Jayan, P. K., Biswas, B. K., et al. (2005). Diversity and genetic resources of wild Vigna species in India. Genetic Resources and Crop Evolution, 52(1), 53-68.

Bohn, L., Meyer, A. S., \& Rasmussen, S. K. (2008). Phytate: impact on environment and human nutrition. A challenge for molecular breeding. Journal of Zhejiang University, 9(3), 165-191.

Chitra, U., Vimala, V., Singh, U., \& Geervani, P. (1995). Variability in phytic acid content and protein digestibility of grain legumes. Plant Foods for Human Nutrition, 47(2), 163-172.

Coelho, C. M. M., Santos, J. C. P., Tsai, S. M., \& Vitorello, V. A. (2002). Seed phytate content and phosphorus uptake and distribution in dry bean genotypes. Brazilian Journal of Plant Physiology, 14(1), 51-58.

Dave, S., Yadav, B. K., \& Tarafdar, J. C. (2008). Phytate phosphorus and mineral changes during soaking, boiling and germination of legumes and pearl millet. Journal of Food Science and Technology, 45(4), 344-348.

Davies, N. T., \& Reid, H. (1979). An evaluation of the phytate, zinc, copper, iron and manganese contents of, and $\mathrm{Zn}$ availability from, soya based textured vegetable protein meat-substitutes or meat-extenders. British Journal of Nutrition, 41(3), 579-589.

Dicko, M. H., Hilhorst, R., Gruppen, H., Traore, A. S., Laane, C., Van Berkel, W. J. H., et al. (2002). Comparison of content in phenolic compounds, polyphenol oxidase, and peroxidase in grains of fifty sorghum varieties from Burkina Faso. Journal of Agricultural and Food Chemistry, 50(13), 3780-3788.
Farias, L. R., Costa, F. T., Souza, L. A., Pelegrini, P. B., Grossi De Sa, M. F., Neto, S. M., Jr., et al. (2007). Isolation of a novel Carica papaya $\alpha$-amylase inhibitor with deleterious activity toward Callosobruchus maculatus. Pesticide Biochemistry and Physiology, 87(3), 255-260.

Forbes, R. M., Parker, H. M., \& Erdman, J. W., Jr. (1984). Effects of dietary phytate, calcium and magnesium levels on zinc bioavailability to rats. Journal of Nutrition, 114(8), 1421-1425.

Fordyce, E. J., Forbes, R. M., Robbins, K. R., \& Erdman, J. W., Jr. (1987). Phytate $\times$ calcium/zinc molar ratios: are they predictive of zinc bioavailability? Journal of Food Science, 52(2), 440-444.

Frossard, E., Bucher, M., Machler, F., Mozafar, A., \& Hurrell, R. (2000). Potential for increasing the content and bioavailability of $\mathrm{Fe}, \mathrm{Zn}$ and $\mathrm{Ca}$ in plants for human nutrition. Journal of the Science of Food and Agriculture, 80(7), 861-879.

Ghavidel, R. A., \& Prakash, J. (2007). The impact of germination and dehulling on nutrients, antinutrients, in vitro iron and calcium bioavailability and in vitro starch and protein digestibility of some legume seeds. LWT - Food Science and Technology, 40(7), 1292-1299.

Grewal, A., \& Jood, S. (2009). Chemical composition and digestibility (in vitro) of green gram as affected by processing and cooking methods. Nutrition and Food Science, 39(4), 342-349.

Hallberg, L., Brune, M., \& Rossander, L. (1989). Iron absorption in man: ascorbic acid and dose-dependent inhibition by phytate. American Journal of Clinical Nutrition, 49(1), 140-144.

Hemalatha, S., Platel, K., \& Srinivasan, K. (2007). Influence of germination and fermentation on bioaccessibility of zinc and iron from food grains. European Journal of Clinical Nutrition, 61(3), 342-348.

Jood, S., Bishnoi, S., \& Sehgal, S. (1998). Effect of processing on nutritional and antinutritional factors of moongbean cultivars. Journal of Food Biochemistry, 22(3), 245-257.

Kataria, A., Chauhan, B. M., \& Punia, D. (1989). Antinutrients in amphidiploids (black gram $\times$ Mung bean): varietal differences and effect of domestic processing and cooking. Plant Foods for Human Nutrition, 39(3), 257-266.

Kim, H. S., \& Zemel, M. B. (1986). In vitro estimation of the potential bioavailability of calcium from sea mustard (Undaria pinnatifida), milk, and spinach under simulated normal and reduced gastric-acid conditions. Journal of Food Science, 51(4), 957-959.

Kochhar, A., \& Hira, C. K. (1997). Nutritional and cooking evaluation of green gram cultivars. Journal of Food Science and Technology, 34(4), 328-330.

Lestienne, I., Verniere, C. I., Mouquet, C., Picq, C., \& Treche, S. (2005). Effects of soaking whole cereal and legume seeds on iron, zinc and phytate contents. Food Chemistry, 89(3), 421-425.

Liang, J., Han, B. Z., Han, L., Nout, M. J. R., \& Hamer, R. J. (2007). Iron, zinc and phytic acid content of selected rice varieties from China. Journal of the Science of Food and Agriculture, 87(3), 504-510.

Lin, P. Y., \& Lai, H. M. (2006). Bioactive compounds in legumes and their germinated products. Journal of Agricultural and Food Chemistry, 54(11), 3807-3814.

Lindsey, W. L., \& Norwell, M. A. (1969). A new DPTA-Tea soil test for zinc and iron. Agronomical Abstracts, 61, 84.

Lotika, B., \& Bains, K. (2007). Effect of household processing on the in vitro bioavailability of iron in mung bean (Vigna radiata). Food and Nutrition Bulletin, 28(1), 18-22.

Madhuri, K., Pratima, S., \& Rao, B. Y. (1996). Effect of processing on in vitro carbohydrate digestibility of cereals and legumes. Journal of Food Science and Technology, 33(6), 493-497.

Makeen, K., Abrahim, G., Jan, A., \& Singh, A. K. (2007). Genetic variability and correlations studies on yield and its components in mung bean (Vigna radiata (L.) Wilezek). Journal of Agronomy, 6(1), 216-218.

Mertz, E. T., Kirleis, A. W., \& Axtell, J. D. (1983). In vitro digestibility of proteins in major food cereals. Federation Proceedings, 42(5), 6026-6031.

Morris, E. R., \& Ellis, R. (1980). Bioavailability to rats of iron and zinc in wheat bran: response to low phytate bran and effect of the phytate/zinc molar ratio. Journal of Nutrition, 110(10), 2000-2010.

Mubarak, A. E. (2005). Nutritional composition and antinutritional factors of mung bean seeds (Phaseolus aureus) as affected by some home traditional processes. Food Chemistry, 89(4), 489-495.

Nout, M. J. R. (2009). Rich nutrition from the poorest - cereal fermentations in Africa and Asia. Food Microbiology, 26(7), 685-692.

Panse, Y. G., \& Sukhatme, P. V. (1961). Statistical methods of agricultural coworkers (2nd ed.). New Delhi: Indian Council of Agricultural Research.

Philip, J., \& Prema, L. (1998). Variability in the antinutritional constituents in green gram (Vigna radiata). Plant Foods for Human Nutrition, 53(2), 99-102.

Randhir, R., Lin, Y. T., \& Shetty, K. (2004). Stimulation of phenolics, antioxidant and antimicrobial activities in dark germinated mung bean sprouts in response to peptide and phytochemical elicitors. Process Biochemistry, 39(5), 637-646.

Rao, B. S., \& Prabhavathi, T. (1978). An in vitro method for predicting the bioavailability of iron from foods. American Journal of Clinical Nutrition, 31(1), 169-175.

Salunkhe, D. K., Jadhav, S. J., Kadam, S. S., \& Chavan, J. K. (1982). Chemical, biochemical, and biological significance of polyphenols in cereals and legumes. Critical Reviews in Food Science and Nutrition, 17(3), 277-305.

Singh, D. P., \& Ahlawat, I. P. S. (2005). Green gram (Vigna radiata) and black gram (Vigna mungo) improvement in India: past, present and future prospects. Indian Journal of Agricultural Sciences, 75(5), 243-250.

Singh, U., \& Jambunathan, R. (1981). Studies on desi and kabuli chickpea (Cicer arietinum) cultivars: levels of protease inhibitors, levels of polyphenolic 
compounds and in vitro protein digestibility. Journal of Food Science, 46(5), 1364-1367.

Singh, S., \& Jood, S. (2009). Proximate composition, in vitro protein digestibility and antinutritional factors of linseed cultivars. Annals of Biology, 25(2), 181-184.

Singh, U., Kherdekar, M. S., \& Jambunathan, R. (1982). Studies on desi and kabuli chickpea (Cicer arietinum) cultivars - the levels of amylase inhibitors, levels of oligosaccharides and in vitro starch digestibility. Journal of Food Science, 47(2), 510-512.

Srikumar, T. S. (1993). The mineral and trace element composition of vegetables, pulses and cereals of southern India. Food Chemistry, 46, 163-167.

Swain, J., \& Hills, W. E. (1956). The phenolic constituents of Pramus domestica. The qualitative analysis of phenolic constituents. Journal of the Science of Food and Agriculture, 10, 63-68.
Tomooka, N. (1991). Genetic diversity and landrace differentiation of mungbean Vigna radiata (L.) Wilczek, and evaluation of its wild relatives (the subgenus Ceratotropis) as breeding materials. Technical Bulletin Tropical Agriculture Research Center, Japan, 28, 4-17.

Vaessen, H. A. M. G., \& Van de Kamp, C. G. (1990). Reference-material-based collaborative test of flame atomic absorption spectroscopic determination of calcium and magnesium in foods and biological materials. Zeitschrift fuer Lebensmittel-Untersuchung und-Forschung, 190, 199-204.

Wyatt, C. J., \& Triana-Tejas, A. (1994). Soluble and insoluble Fe, Zn, Ca, and phytates in foods commonly consumed in Northern Mexico. Journal of Agricultural and Food Chemistry, 42(10), 2204-2209.

Yoon, J. H., Thompson, L. U., \& Jenkins, D. J. A. (1983). The effect of phytic acid on in vitro rate of starch digestibility and blood glucose response. American Journal of Clinical Nutrition, 38(6), 835-842. 